\title{
En, man eller du?
}

\author{
Det har stått mange slag om språket. Ett av dem dreide seg om bruken av pronomenene en og man. \\ Nå er det motepronomenet du som gjelder.
}

Enkelte mente for noen tiår siden at man burde forkastes på norsk fordi det kommer fra tysk. En var ordet som nordmenn burde bruke (1).

Man og en er imidlertid ikke helt overlappende - man har mer begrenset bruk enn en. Man kan nemlig bare være subjekt og har ingen genitivsform. Det kan ikke hete mans foreldre. En kan være subjekt og alt mulig annet, og ordet har genitivsform: ens foreldre. Det må altså hete Det gjør inntrykk på en og Det kommer an på ens innstilling $(1,2)$.

\section{Man er i fare}

I løpet av de siste tiårene har språkbruken endret seg. Stadig flere bruker $d u$ som ubestemt pronomen. I setningen «Når du står der med tre leger foran deg, er det lett å bli taus» ville man tradisjonelt brukt «man» eller «en». «Du er litt utafor når du har mensen,» sa en student til sin mannlige lærer da hun skulle redegjøre for hvorfor hun ikke hadde levert en oppgave i tide (3). Denne bruken er inspirert av engelsk you og derfor visstnok uutryddelig, så frastøtende den enn er, skriver Finn-Erik Vinje på bloggen sin (4). Han kaller det for «du-fjolleriet» $(5,6)$.

Når $d u$ brer seg på denne måten, blir man presset tilbake (4). Ordet har i lang tid hatt trange forhold i norsk. I nynorsk er man utestengt, det blir i regelen ikke brukt i dialektene, og bruken blir ikke oppmuntret i skolen (6).

\section{En reiser fremdeles}

Ingen har karikert den gamle offisielle bruken av «en» så ettertrykkelig som Odd Eidem (1913-88) i boken Zikzak (1967). Han hadde fått et reisestipend på 900 kroner fra Kirke- og undervisningsdepartementet (uten å ha søkt om det). Et år senere purret departementet på «reiseinnberetning» med disse ordene: «En kan ikke se at det er kommet reiseinnberetning.» Eidem svarte ikke, og etter tre måneder mottok han sålydende departementale «skriv»: «Idet en viser til skriv som en sendte en den 4. mars i år, kan en fremdeles ikke se at en har fått svar. En tør gjøre merksam på at en har plikt til å sende reiseinnberetning.»

Da Eidem fremdeles unnlot å svare, kom dette brevet rekommandert: «En gjør med

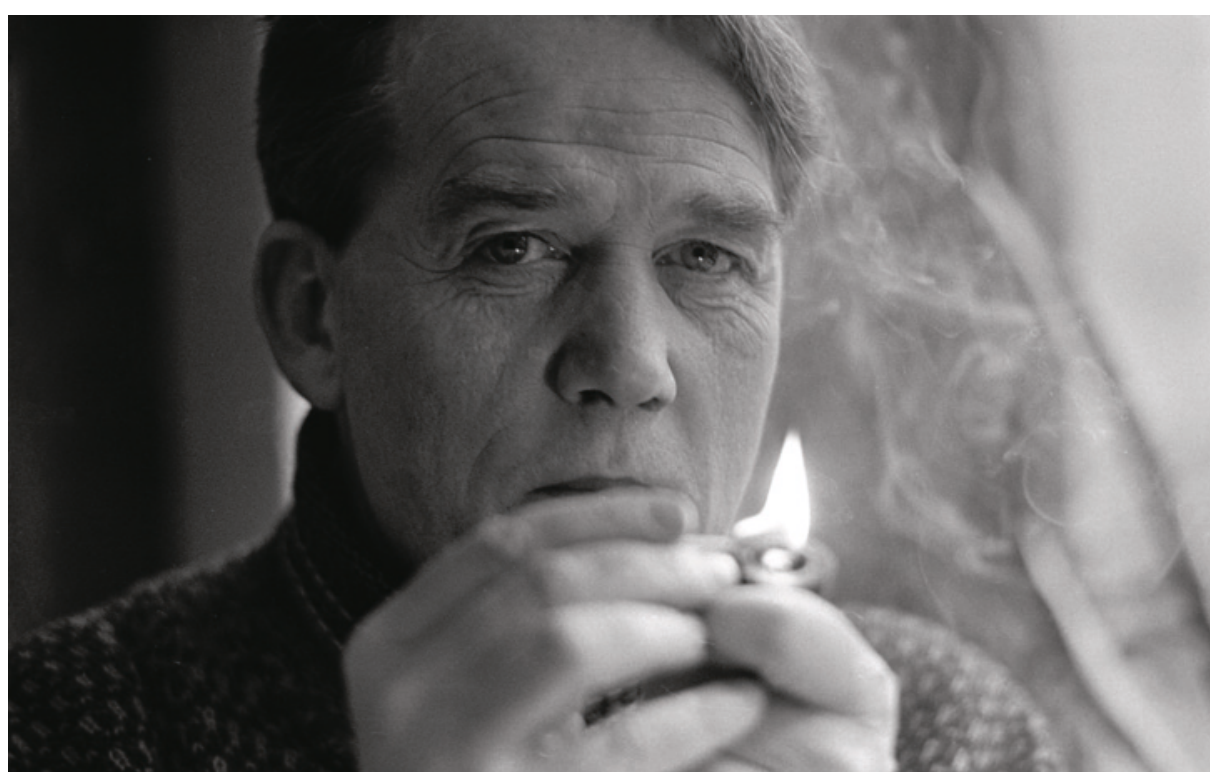

Journalisten og forfatteren Odd Eidem fotografert i 1967, samme år som boken Zikzak utkom. I den harselerte Eidem i et av sine flanerier over byråkratiets bruk av det ubestemte pronomenet en. Foto: NTB scanpix

dette merksam på at en to ganger tidligere har bedt en om reiseinnberetning. Da en ikke kan se at slik er skrevet, enda en har plikt til det etter loven, må Departementet kreve at en retter seg etter gjeldende føresegner. Saka vil ellers få konsekvenser.»

Da svarte stipendiaten: «En takker for de tre skrivene en har fått fra en. En tillater seg med dette å melde at en for reisestipendet har kjøpt påhengsmotor, og at en reiser fremdeles» (gjengitt fra referanse 1).

\section{Tidsskriftet og jeg}

I Tidsskriftet brukes man som ubestemt pronomen, ikke en $(7,8)$. Men bruken bør uansett begrenses. Man legger fort et upersonlig og distansert preg over teksten. Man (sic) bør angi hvem det dreier seg om. Bruk «jeg» eller «vi» hvis det er mulig (9). Det er ingenting i veien for å skrive jeg når man mener «jeg» $(10)$.

\section{Erlend Hem}

erlend.hem@medisin.uio.no

Erlend Hem (f. 1970) er dr.med. og assisterende sjefredaktør i Tidsskriftet.
Litteratur

1. Klouman S. Moro med ord: litt om ordenes vandringer, historie, slektskap og hemmeligheter. 2. utg. Oslo: Aschehoug, 2000: 219-20.

2. Vinje F-E. Sterkere enn man selv. Finn-Erik Vinjes blogg 1.11.2012. www.finnerikvinje.no/blog/ $? p=15998(1.8 .2013)$

3. Vinje F-E. Sharon Stone og Kjell Askildsen. FinnErik Vinjes blogg 20.5.2012. www. finnerikvinje.no/ blog/?p=261 (1.8.2013)

4. Vinje F-E. Man er i fare. Finn-Erik Vinjes blogg 5.3.2012. www. finnerikvinje.no/blog/? $p=13855$ (1.8.2013).

5. Vinje F-E. Du-fjolleriet. Finn-Erik Vinjes blogg 29.6.2012. www. finnerikvinje.no/blog/? p=129 (1.8.2013).

6. Vinje F-E. Språk 2004: en situasjonsrapport. Oslo Schibsted, 2003: 74-6.

7. Forfatterveiledningen M. Tidsskrift for Den norske legeforening. http://tidsskriftet.no/Innhold/ Forfatterveiledningen/Spraak/Ordliste/M (1.8.2013).

8. Ødegaard R. Språket i Tidsskriftet. Tidsskr Nor Lægeforen 2006; 126: 71.

9. Generelle språkråd. Forfatterveiledningen. Tidsskrift for Den norske legeforening. http://tidsskriftet.no/Innhold/Forfatterveiledningen/ Spraak/Generelle-spraakraad (1.8.2013).

10. Vinje F-E. Riktig norsk. 3. utg. Oslo: Cappelen Akademisk, 1999: 142-4. 